\title{
Children's self-image following abuse, development of resilience and family context impact: A Clinical Psychodynamic approach.
}

\author{
Pilios-Dimitris Stavrou \\ Department of Psychology, University of Athens, Athens, \\ Greece, 10679/Laboratory of Clinical Psychology, \\ Psychopathology and Psychoanalysis (PCPP), \\ University Paris Descartes - Sorbonne, Paris, France.
}

\begin{abstract}
Objective The purpose of this research was to study the consequences of intra-family physical abuse by the parent(s) on the development of children's self-image, i.e. on the way they perceive themselves. Moreover, a second objective was to investigate if resilience can occur due to a new environment, and especially a new family, which will provide security and warm to the abused children. Methods The sample consisted of two young children. Both of them were seen three different times during sixteen months. The first evaluation, which happened with the use of projective tests, similarly to the other two, took place two months after the children were placed into a host family, the second four months after the first session and the third one a year after the second session. The projective tests used were: "The Human Figure Drawing (HFD)", "Patte Noire" (" Black Foot"), "Children Apperception Test (C.A.T.)", "The Family Drawing Test" and the "House-Tree-Person test (HTP)". Results The tests revealed that the emotional deprivation caused by the abusive behavior of the biological parents resulted in the development of a negative self-image. Furthermore, children with failing parenting models who were placed into a host family after their abuse and met one or more "resilience guardians", who have been identified as positive identifiers, presented behaviors characteristic of resilience.
\end{abstract}

Keywords: children's abuse, self-image, resilience, familial context

\section{INTRODUCTION}

Physical abuse can take place very early in children's life and at a crucial moment of their development. Abuse can begin in the first months of the child's life and can impact somatic, emotional, psychological and intellectual development. Florida Statute 39 defines "Abuse" as any willful act or threatened act that results in any physical, mental, or sexual abuse, injury, or harm that causes or is likely to cause the child's physical, mental, or emotional health to be significantly impaired.

Data released by the Children's Bureau in January 2017 revealed that in 2015, about 683,000 abused children were identified in US. These data showed in addition that both sexes are affected equally. Of the substantiated cases in the US in 2015, 75.3\% involved neglect (including medical neglect), 17.2\% physical abuse, $8.4 \%$ sexual abuse, and $6.9 \%$ other forms of abuse including psychologic abuse. Many children were victims of multiple types of abuse.

The present research was limited to the physical abuse and its psychological consequences to the children. Physical abuse may involve hitting, shaking, throwing, poisoning, burning or scalding drowning, suffocating, or otherwise causing physical harm to a child. Physical harm may also be caused when a parent fabricates the symptoms of, or deliberately induces, illness to a child. Children under 4 years old and those with special physical, developmental, or 
mental-health needs are at higher risk for being victims of abuse. After three years of age, they start school and therefore they are better protected by the physical environment.

Physical abuse can have different psychological consequences and thus the reactions of the children to the violence they undergo vary. They can be in a state of confusion and remain silent, folded on themselves psychically. They can also adopt a fearful position. Moreover, they are often sad, scared and very inhibited: they will stay away from other children and they do not want to play with their peers. However, we can observe in children a continual agitation, disturbances of the sleep but also somatic consequences (vomiting, headaches). They often experience anxiety and will express it through bodily responses. Physical abuse, in addition, can significantly predict aggressive behavior [1]. Abused children can furthermore use psychic defenses. They will distance themselves from everyone and will sometimes avoid any physical contact with the adult. Nevertheless, there are children who will often try to find security from other adults, which can be interpreted as attempts to establish a secure social connection.

Or, contrary to these behaviors, children can also give the impression of a good adaptation to their social environment. But under this apparent good adaptation is often hiding a submission and a compliance too apparent. For D.W.Winnicott [2], this is the expression of a "false-self" in children. Winnicott uses the term "false self" to describe the defensive organization formed by the child as a result of inadequate mothering or failures in empathy. "False Self" is a defense, a kind of mask of behavior. The identity disorder, which is present among children, is very often accompanied by emotional greed.

Furthermore, children's abuse has important consequences on their self-image, which we will investigate in this research. According to F. Dolto [3], the narcissism of the child, which is the love they have for themselves, is built in the first months of their life, and especially through their relationship with their mother. Indeed, it is through the gestures of the mother during the care and the satisfaction of their needs and desires that the children will be able to know and recognize themselves and receive the image of their value or not. This primary narcissism is then developed by the introjection of the contacts and relationships that the child has with their mother. This is how their attitude towards themselves, the image they have of themselves and therefore the love that they will have for it, depends on the love their mother had for them during, especially, the first months of life, that is, the oral stage, followed by the anal stage. This idea of the introjection of the mother's love was already present in Freud's theory [4], by his notion of "secondary narcissism". The child will introject the love they felt from their mother. Freud speculates that secondary narcissism develops when individuals turn object affection back on themselves. The result is that an individual becomes cut off from society and disinterested in others. Freud postulates that such an individual will have low self-esteem. D.W.Winnicott [5] speaks of the mother's mirror role. It is through the face of the mother, during the care she gives to the child, that the child perceives themselves. As reported by Winnicot, when the baby looks at their mother, what they see is themselves. Therefore, the mother's face and what she expresses has a vital role in the development of the child's selfimage, and therefore in their emotional and mental development.

According to these theories, the family environment and more specifically the first motherchild relations are crucial for the development of children's self-image. Thus, a negative family environment and mother-child contact can influence the child's self-image.

A fragile and negative self-esteem, which can be defined as a negative self-image and a fragile feeling of the child's own worth, does not allow children to be resilient after an abuse. The notion of resilience was created by M. Rutter, N. Garney and E. Werner and was particularly 
taken up by psychiatrist B. Cyrilnik [6] who states that the concept of resilience, which has nothing to do with invulnerability, belongs to the family of defense mechanisms but it is more constant and evolutive, so controllable and carrying hope. The notion of resilience is more than resisting, it is also learning to live, which emphasizes the adaptive and evolving aspect of the ego. According to Gilligan [7] the development of the resilient functioning of an individual is based on a tripod consisting of 3 buildings blocks of resilience: the feeling of having an internal security base, the self-esteem and the feeling of one's own efficiency. M. Rutter [8] considers necessary the existence of a good development of the self-esteem in resilient individuals. In addition, André and Lelord [9] underline that self-esteem has three dimensions: self-love, selfvision and self-confidence. Thus, the self-love and self-confidence will help the child after an abuse to rebuild themselves

Resilience is a dynamic developmental process. It responds to different internal and external conditions to the subject and therefore is variable according to its internal environment and changes in the context environment in which it evolves. A change of the familial environment which has abused the child may help the abused child to develop their self-esteem and to be resilient. It can be noted that any abused child cannot be resilient without a strong psychological base, which implies that. A warm familial context may thus help the child to develop a positive self-image.

\section{CURRENT RESEARCH}

The current research aims was to study the consequences of intra-familial physical abuse, by one or both parents, on the development of the children's self-image, that is to say on how they perceives themselves, as well as the possibility to develop a positive self-image after a change of familial context. The second object of this research was to study if resilience can occur due to a new environment, and especially a new family, which will provide security and a warm context to the abused children.

In the abused children, the experience of bad early relationships with their parents and especially with their mother, will influence their self-image. However, this self-image can on the other side be influenced in a positive way by a new, warm familiar context which can help children to become resilient.

Thus, this study's aim was to confirm two hypotheses.

Hypothesis 1: The emotional deprivation that characterizes the abusive relationship of the parents towards their child, would result in the development of an altered and negative selfimage.

Hypothesis 2: The change of the familial context and the supply of a new, warm environment will reinforce children's self-image and lead to a resilience.

\section{Participants}

\section{METHODOLOGY}

For this research, we met two children: Anna six years old and George seven years old (the ages they had when we last met). These two children were abused by their parents from an early age and they were placed after a legal decision to a host family at the age of five for Anna and six for George. We also have chosen children of different sex in order to observe if there is any difference in their behavior and results.

Anna was physically abused by both her parents, especially her father. She was removed from her family at five-year-old following a social inquiry and a legal decision. She was placed in a host family. Her little sister who was a baby stayed with the parents but she will also be placed 
the next year to a host family. Anna's behavior at her new home at first varied between total isolation and aggressiveness towards the other two children of the host family (a boy of 10 years old and a girl of 6 years old) while she was close to the adults.

George is the younger boy of a family of three children. Following an investigation, he was removed at six-year-old with his two older brothers from his family, known as abusive and perverse. He was placed at the age of six in a host family. The parents of this second family mentioned a significant need for reinsurance but also abandonment anxieties as well as self and hetero-aggression.

\section{Place of research}

Both children came in our office with the company of the parents of the host family.

\section{Materials - Procedure}

We met three times with both children. The first time was two months after their placement at the host family, the second one, four months after our first session and the third one, one year after the second session.

During our first session we had an individual interview with each child. This psychology assessment was our first contact with the children as we hadn't met before. At first, we proposed them to make a drawing of human figure before the realization of the first projective test "Patte Noire" ("Black-Foot"). An indirect approach such as a projective drawing facilitates the expression of thoughts and feelings. It is an effective instrument that helps in viewing the inner world, unconscious defenses and conscious resistance [10]. Moreover, a projective drawing test is a tool that allows also achieving information concerning the sensitivity, the selfesteem of the patient and his interpersonal interaction with the environment.

The Human Figure Drawing (HFD) was used as a projective test during our first session. This projective drawing is used primarily to see indicators that may signify emotional problems in children. Many studies [11] have shown that when children draw a human figure of the same sex, we can consider that this human figure is for the children the representation of themselves. While when they draw a human figure with a different sex gender than theirs, this shows the children's representation of the other. The children were provided with a pencil and blank sheet of paper and were told to make the best possible drawing of the whole figure of a person.

Upon completion of the first projective drawing, children were asked to carry out the test of "Patte-Noire" (PN), a French projective test created by L. Corman [12]. This projective test presents three little pigs, including Patte Noire (Black Foot), which is a little big with a task on its foot, and two adults' pigs. There are also other animals like sheeps. This test includes 17 cards, which show Patte Noire with other pigs through different themes, such as oedipal themes, themes of fraternal rivalry, of punitive reversal against oneself, themes of anal or oral sadism, the ideal of the self, solitude etc...

The first card presented to the child is the frontispiece, which serves us to present the main character, who is Patte Noire. It also enables us to ask the child what the sex and age of Patte Noire could be, as well as for the other two pigs and both adults, and what the family connection between all of them could be.

The other cards were all presented in front of the child and the child chose themselves the order of presentation. We asked of them to tell a small story from what they saw on each card. 
After each card, the child was asked what character they would have liked to be in the story he just told. Furthermore, at the last card the child was asked what the three wishes that Patte Noire would ask of the fairy. This test aims to evaluate how the child copes with the different conflict situations presented by the boards.

This test may be of value for differential diagnosis and also for a more detailed exploration of conflict topics of disturbed children [13].

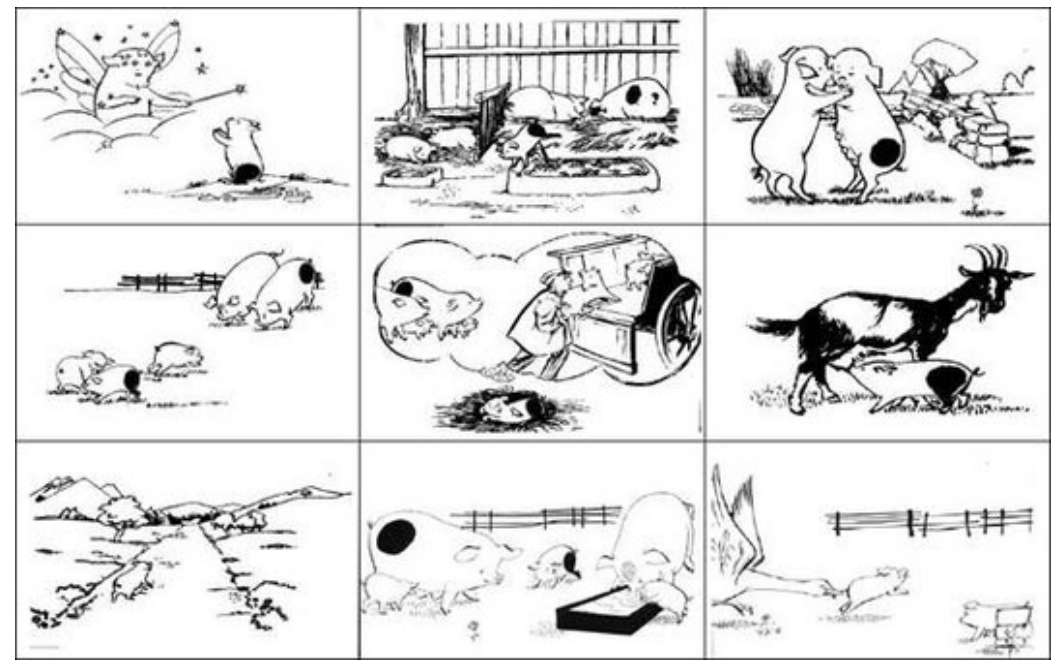

Figure 1. Example of the cards of the "Patte-Noire" Test

During the second session, Children Apperception Test (C.A.T.), created by L. Bellak, and S. Bellak in 1949 [15], was used. This projective measure let us acquire information about children's personality and psychological processes. The test includes a series of 10 quasiambiguous animal pictures to which the child is asked to create a story. This assessment technique was designed to obtain information about psychological functioning through the specific mechanism of projection.

During the second session, the Family Drawing Test, created by Burns and Kaufman in 1972, was also used. This tool enables the children to express their difficulties or their adaptabilities to their environment. In addition, this tool will let us know what the children's place in the family is as well as how they represents and perceive themselves and give us information about their self-esteem [14]. The instruction of the test was "draw your family". If the children were asking which family, as they are now in a new family, the instructor was giving the answer «the family you want».

Finally, we met the children one year after our second session. During this session, we had an interview with the children and we used the House-Tree-Person test (HTP) and again the Human Figure Drawing in order to compare our observations with those at the first and second session. The HTP test is a projective test designed to measure aspects of a person's personality. It was developed by John Buck in 1948 and updated in 1969 [16]. The subject receives a short instruction to draw a house, a tree, and the figure of a person. Once the subject is done, they are asked different questions about their drawings. The assumption is that when the subject is drawing they are projecting their inner world onto the page. 


\section{Anna's results}

\section{First session}

\section{The Human Figure Drawing: (appendix 1)}

A lack of sexual identity is noticed. Anna draws a deformed head and a rectangular as body with two lines as hands. The figure is not sexed. The eyes, the nose and the mouth are represented by simple and very small lines, which removes all expressiveness of the face. Those too small characteristics of the face give the impression that she maybe wants to hide the figure's expression. After the drawing she says that it's a girl. We can thus suppose that it is her own image that she projects to the sheet. The image she seems to have of herself appears as a negative image: her image appears indeed as deformed, without expressions and without the possibility to walk, sign of a deep narcissistic wound.

\section{The Patte Noire test:}

The order of the cards is as it was chosen by Anna

\section{Frontispiece (Frontispice)}

Anna is projected into the main character of Patte Noire, which according to her is a five-yearold girl like her. In addition, the parents are not recognized as such, but they are the two neighborhoods of Patte Noire and of her two sisters. The feminine image of one of the parents is not even mentioned.

\section{Feeding 2 (Tétée 2)}

Anna makes a simple description of the elements of the card, without making a story composed of affects. The orality, which the card presents, is expressed by her but attributed to the father who according to Anna breastfeeds. She therefore ignores the maternal image in this card and the parental roles seem to be confused for her.

\section{Hesitation (Hésitation)}

Anna for once again describes the board. The themes of ambivalence, exclusion and fraternal rivalry that the card provokes are not expressed. Thus, the question for a possible repression is posed.

\section{Battle (Bataille)}

For the first time a story appears accompanied by affects. However, this is a scene of violence and suffering. She reacts to the sadistic theme of the card saying that the little white pigs pull the shirt of Patte Noire. In addition, she identifies herself with the mother pig which is away from the scene of violence. In that way she tries to have a distance from the violence.

\section{Holding (Portée)}

For once again no link is given between each of the elements. The orality is expressed in this card, in a devouring way («drink from the other»). She identifies herself with the newborns who drink from the other, showing a regression at the oral sadistic stage.

\section{Trough (Auge)}

The idea of urethral sadism raised by the card is well expressed by Anna (while the parents sleep, Patte Noire pee in the water), as well as the idea of a future punishment (parents sleep but Patte Noire will be punished). On the other hand, this urethral sadism is not assumed because she identifies herself with the sleeping pig who does not see the scene, and not with Patte Noire, projecting in this way this impulse that she cannot accept. 


\section{Departure (Départ)}

For this card she expresses a feeling of loneliness, even depression (Patte Noire is all alone and wants to see her parents). Moreover, she will use after a long time the personal pronoun "she" when she will talk about the feelings of Patte Noire which signifies that she projects her own effects on the character.

\section{Feeding 1 (Tétée 1)}

Orality is expressed in a relatively aggressive way ("he pulls because he wants to eat"). Anna tells that Patte Noire, at which she identifies herself on this card, pulls the parent who will feed it (she uses again the pronoun "he" even if she identifies herself with Patte Noire).

\section{Short scale (Courte echelle)}

No feeling or connection between the two pigs is expressed for this card.

\section{Goat (Chèvre)}

No surprise from Anna is expressed against the fact that it is a goat that feeds the little pig. The theme of replacement mother is not therefore emphasized by Anna.

\section{Kiss (Baiser)}

Anna describes a scene of violence (They fight). Moreover, the feeling related to this scene is that of fear (Patte Noire is hiding). Anna identifies herself with Patte Noire who is away from violence and simply observes. For once again Anna has no role in the action but is a mere observer.

\section{Gander (Jars)}

Anna tells a scene of violence where the theme of kidnapping is implied (the little pig cries because it wants his mother. The bird wants to take it). She also identifies herself with the only character who is not in the scene of violence and observes from a distance.

\section{Dirty games (Jeux sales)}

She still identifies herself with the only character who is not dirty and who is out of the scene: that is to say, the person who does not risk being punished. No aggression, by the anal theme that suicide the board, is expressed.

\section{Dream mother (Rêve mère)}

The mother is not identified as such and no link is expressed between the two pigs.

\section{Dream father (Rêve père)}

Anna says the same thing like in the previous card (the pig sleeps). The sexual difference between the two parents is not expressed (as before).

\section{Night (Nuit)}

The primitive scene theme is not expressed. The parents on the picture seem not perceived or are ignored. She expresses the idea of correction, punishment (Patte Noire had a spanking).

\section{Hole (Trou)}

Anna expresses a feeling of loneliness by Black-Paw. Patte Noire claims its mother.

\section{Cart (Charrette)}

A theme of separation of the children from their parents is expressed. Anna, however, still identifies herself with the pig who only watches. 


\section{Fairy (Fée)}

Anna does not seem to want her difference (the black foot) as if she wanted to erase what makes her identity, what distinguishes her from the others.

\section{Choice}

Her favorite card is "Fairy" and the least loved is "Night".

\section{Second session}

\section{C.A.T. test:}

Card 1: Anna says that the mother discipline the children during the dinner because they make fall the plate. We can see that even if the scene can be described as a happy family scene, Anna described a negative one where the children are disciplined.

Card 2: Anna mentions that the little bear isn't strong and will fall. We remark so that Anna underlines again only a negative aspect of the scene. In addition, she presents the little bear without strength. This image of the little bear can let us think that it's maybe the image of herself that she projects to the little bear.

Card 3: The lion as presented by Anna is alone. It is sitting on a chair with a cigarette and no one comes to see it. Anna is wandering if it is its fault that it is alone. A feeling of depression and culpability is mentioned by Anna.

Card 4: Anna speaks only for the baby without mentioning anything for the mother. The little is bicycling and it is afraid to fall. A feeling of fear is again expressed.

Card 5: The little bear is presented as withdraw. Loneliness is once again the feeling of the scene's character as in the following card (card 6) in which the little animal is alone and doesn't sleep.

Card 7: The monkey is in danger and the blame is on it. It embarrasses the tiger. Again, Anna expresses a feeling of fear and culpability.

The feelings of sadness and loneliness are also expressed by the characters of the scene in the card 8 ("The little monkey is sad. It is afraid of talking to its mother"), card 9 ("The rabbit is alone at its bed and cannot find anyone. It cannot get out of its bed") and card 10 ("A dog which cries"). At the last one, as at many other cards before, Anna does not refer to the mother or another family member. We can also remark this through the test of Patte Noire.

\section{The Family Drawing Test: (appendix 2)}

The characters as in the drawing of the human figure have no sex differences. The parents are drawn smaller than the children which signifies a failure of the parental image. The relations between the parents and the children seems absent. Indeed, parents are drawn apart from the children. Moreover, each one has his own house (except the little sister) as if each one had his own life without connection between them. The size of the houses is different according to the characters. Parents have the largest houses despite their smaller size. Anna has a very small house despite the importance of her character by its size.

\section{Third session}

\section{The Human Figure Drawing: (appendix 3)}

We repeated a drawing of the human figure in order to compare the drawings. According to Anna this time it also is a girl of her age. Contrary to the last time, the sexual identity was indicated by the clothes and the characteristics of the face and nothing on the drawing was altered.

\section{The House-Tree-Person test (HTP): (appendix 4)}

Anna drew a house, a tree and a girl. The three of them had a big size. She also drew a sky and a sun. Furthermore, she colored her drawing. Regarding the house, she drew a big one with two 
windows, a door, a roof and a chimney. The tree, drawn by Anna, was also big. It has a crown and a tall trunk. Like the tree and the house, the person in the drawing has a big size. Anna drew a girl, who following our question is a girl of her age, giving thus to the person a sexual identity. The head is larger than the body. Anna drew two eyes with eyelashes, a nose and long hair. The girl is smiling. Regarding the girl's body, Anna drew a neck, two hands with fingers, two legs and feet. The girl has a dress and shoes. Finally, she used bright colors in order to complete her drawing.

Anna, after our questions about the person (Who is this person? How old is that person? How does that person feel?), mentioned that the person is her, that she has six-year-old and that she is happy because she has a beautiful house and because now she can play with all the members of her family. She added that the girl has a beautiful dress, long hair and that her favorite color is pink. As for the house (Who lives here? Are they happy? What is the house made of? What is it like at night? Do people visit the house? ), Anna said that it is her with her family who live in the house and that everyone is happy. She answered that in the night everything is calm and that she feels safe. According to her, it is a happy house and many people visit it.

Finally our questions about the tree were: "What kind of tree is this? How old is it? What season is it? Has anyone tried to cut it down? What else grows nearby? Who waters the tree? ". Anna answered that it is an apple tree, not very old and that as it is in her house's garden her new parents water it. She said that it is summer and that no one tried to cut it down because it is a beautiful and a very big tree.

\section{George's results \\ First session}

\section{The Human Figure Drawing: (appendix 5)}

First, we can notice that the figure he draws is very small. He places it on the left of the sheet and separates the sheet at two sides by a line. This refers to a feeling of loneliness, exclusion but also lack of confidence or even depression. The head and the body are well appointed, the face characteristics are simple circles and it does not smile. A lack of sexual identity is also expressed by George.

\section{The Patte Noire test}

The order of the cards is the order that George chosen

\section{Frontispiece (Frontispice)}

At first, he identifies the two little white pigs as being the brothers of Patte Noire. However, he does not give sexual identity or even age to the main character, Patte Noire. We can therefore think that he protects himself from any possible identification with the character. Parents are well recognized as such and there is no confusion about their sexual identity.

\section{Trough (Auge)}

He describes the scene of uterine sadism that is directed at the parents, while recognizing the forbidden aspect of this act. However, he does not identify himself with the actor of this sadism and he prefers not to take a position.

\section{Departure (Départ)}

George repeats the verb "fall" three times. It's Patte Noire that falls. In addition, the name of the character is blurred. An aspect of loneliness appears. Furthermore, George does not identify himself with Patte Noire, which suggests that this feeling of loneliness can be a source of anxiety for him. 


\section{Hole (Trou)}

George will take an expression of fear. But for once again he does not identify himself with the character.

\section{Night (Nuit)}

He describes a scene of fear, of danger. The image of the parental couple seems repressed since George describes two pigs and an adult.

\section{Cart (Charrette)}

George transforms the scene of separation of the card into a meal of reunion between a child and his family. We can note a defense of George against the anxieties that follows the theme of separation. In addition, he identifies himself with Patte Noire, which is expected according to him by his family. Thus, he adopts a child's place expected and surely desired by his family and especially by his parents.

\section{Dream mother and dream father (Rêve mère et rêve père)}

No paternal or maternal image appears. He only describes Patte Noire sleeping.

\section{Dirty games (Jeux sales)}

The anal sadism that the card presents is well expressed and is directed at the father.

\section{Gander (Jars)}

The anal sadism is evoked by George who says that the bird that sees in the scene is naught. Punishment accompanied this sadism immediately because he says that it is the fault of Patte Noire. Finally, he identifies himself with all the characters what can be a defense mechanism against the violence that evokes the board.

\section{Kiss (Baiser)}

The sexual identities of both parents are not mentioned and later he denies the presence of parents.

\section{Goat (Chèvre)}

The replacement foster mother is seen by George but this will not surprise him.

\section{Short scale (Courte echelle)}

No link is indicated between the two characters and the concept of "holding" that represents the card is not expressed at all. For once again he identifies himself with both characters and it seems that he does not want to position himself in this scene.

\section{Feeding 1 (Tétée 1)}

He identifies himself with the two characters showing that it may be difficult for him to know what place he occupies.

\section{Feeding 2 (Tétée 2)}

He expresses a confusion regarding the role of each parent. It is the father according to him that feeds the children.

\section{Hesitation (Hésitation)}

For the first time he identifies himself with Patte Noire because it is he who claims his thirst. 


\section{Battle (Bataille)}

George presents a scene of violence with a punitive reversal to himself. Patte Noire is assaulted because of its behavior. Moreover, as the scene is characterized by the feeling of fear he identifies himself with both parents who are away from the scene of violence and who are therefore neither the aggressor nor the victim.

\section{Holding (Portée)}

He identifies himself once again with all the characters of the scene in order not to be involved in themes like exclusion.

\section{Fairy (Fée)}

He does not want his difference and he expresses his fear of being alone.

\section{Choice}

His favorite card is fairy and he does not want to mention a card that he doesn't like.

\section{Second session}

\section{C.A.T. test}

In the first card Georges says that children were dirty with food and they were punished by their mother. The theme of punishment emerges by George at this card as well as in card 4 ("The little animal falls from his bicycle and it is punished by his mother") and in card 8 ("The mother disciples the little monkey. It is his fault").

In the second card George mention a lack of strength felt by the little bear which is according to him too little and cannot help the other bears. At the end he mentions that the rope will be cut.

Feelings of loneliness and weakness are also expressed by George at card 3 ("The lion is alone and weak"), card 5 ("The little is far from its parents. It is sad. "), card 6 ("The little animal is playing alone. There is no one in the bedroom"), card 7 ("The monkey is alone and in dangerous. It does not have the capacities to fight with the tiger") as well as the feeling of sadness (Card 9: "The rabbit asks for light. It cannot sleep, it is sad". Card 10: "The little dog is sad. The other dog is talking to him").

\section{The Family Drawing Test: (appendix 6)}

George draws only three little children apart from their parents. His drawing projecting certainly his biological family in which the three children are separate from their parents.

\section{Third session}

\section{The Human Figure Drawing: (appendix 7)}

We used again as in the first session a drawing of the human figure in order to compare the drawings. This time the figure will be a boy. George will draw a much bigger human figure than in the last time which will be on the one side of the sheet. He drew a round-shaped eye and a nose. He also drew short hair and a boy's outfit.

\section{The House-Tree-Person test (HTP): (appendix 8)}

George drew a house, a tree and a boy. As regards the house, he drew two windows, a door, a roof and a chimney. The tree, drawn by George has a crown and a trunk. The person drawn is a boy of his age, giving thus to the person a sexual identity. The head is larger than the body. George drew two eyes, a nose and short hair. The boy is smiling. Regarding the boy's body, George drew two hands and two legs. He is wearing a T-shirt and a short. 
George, following our questions about the boy (Who is this person? How old is that person? How does that person feel?), mentioned that the person is he, that he has seven-year-old and that he is happy because he will play with his friends. As to the house (Who lives here? Are they happy? What is the house made of? What is it like at night? Do people visit the house? ), George said that in the house it is he and his new family who live. He answered that they are happy and that during the night everyone sleeps. According to him, it is a happy house and his new friends visit it.

Finally, our questions about the tree were the same questions used for Anna. George said that he does not know what kind of tree it is or its age but he mentioned that it is outside his new house and that all the people water it. He said that it is spring and that no one tried to cut it down.

\section{DISCUSSION}

During the individual session with Anna, she remained calm. Communication with her was difficult to establish. When the session was over, she left the office without saying anything. At the first two sessions with Anna a fragile and negative self-image was observed. A fragile selfimage is noticed, through a feeling of insecurity, expressed by her on several cards of the two projective tests (Patte Noire, C.A.T.) and essentially on the cards which evoke themes of aggressiveness, loneliness and separation. She expresses most of the time no connection between the characters presented in the cards. At the test of Patte Noire, Anna practically uses only personal pronouns to refer to each character as if there were no family ties between them. In addition, at this test orality is expressed through the themes of devouring, of incorporation or aggression. At the first card representing orality, the nurturing role is attributed to the father making us wonder about the mother's role for Anna. Violence frequently appears in Anna's speech, either in a form of aggression or in a form of punishment. The themes of separation and loneliness are also mentioned very often in Anna's speech. She expressed feelings of solitude and a fear of separation at both test. She also mentions very often, through the characters of the animas of the C.A.T. test, a feeling of weakness.

Apart from that, Anna's identification at the Patte Noire test with the only character who is outside of the action and observes, in particular at the cards with themes of violence or possible punishment, is underlined. She tries by this way to put away actions marked with violence. While Anna had described Patte Noire as a girl of the same age letting us think that she will be projected in the various adventures of Patte Noire, she uses latter most of the time the pronoun "he". This can lead us to think that she does not want to get involved in the scenes and in what they represent. A. Freud [17] named this mechanism of defense as a retraction of the ego. She said that the child is confined to the role spectator, which allows them not to give birth to any painful impression. In addition, to the "Fairy" card, the wish expressed by Patte Noire is to no longer have this leg that differentiates it from others, and that makes its identity as if Anna did not want to be different from others.

The drawing of the human figure and his face gives the impression of a negative image. While according to Anna it is a girl of her age, the absence of a sexual identity underlines a deep narcissistic wound. This absence of symbolic meaning makes us think of Anna's deprivation of the "skin-ego"[18]. The drawing of the family shows again figures without sexual identities and the relations between the parents and the children seems absent.

Regarding to the first two sessions with George, we notice that George has a self-image that is rather depressed and insecure. On several cards of Patte Noire test, the story of George has a depressive aspect. He shows a fear at the theme of departure and loneliness. The theme of 
separation is transformed into a reunion scene. In the last card, he evokes a fear of finding himself alone. George expresses very often a feeling of insecurity, a fear of separation or loneliness which is underlined especially with the repetition of the word "fall" at the Patte Noire test. The depressive aspect is also found in the drawing of the human figure where the human is positioned on the one side of the sheet and he is very small. A feeling of loneliness and weakness is very often mentioned at the C.A.T. test. Aggression is also present by George in several cards at C.A.T. test and as well as a theme of violence with a punitive reversal. We notice an aspect thus fragile of his self-image. We therefore observe that his self-image is on the one hand depressive and insecure and on the other hand aggressive and therefore negative. At the Patte Noire test, there is a confusion about the role of each parent. In addition, in the majority of the cards, he identifies himself with none, or with all the characters or with a person who is outside the action. Like Anna, he stays a simply observer and it is difficult for him to participate to the action. Furthermore, in the first card, he gives no sexual identity, nor age to the main character which can lead us to think that he avoids any possible projection of his affects in the cards.

The theories of Winnicott, Dolto and Freud about self-image, which is built by introjection of the first relations with the mother, mentioned at the beginning of this study, converge with these results. The results of the two sessions show us that these two abused children have developed a fragile, insecure and negative self-image. This confirms our hypothesis that the emotional deprivation that characterizes relationships between abusive parents and their children will alter the self-image of the child. We observe a weakened ego marked by a feeling of insecurity.

Therefore, the negative familial environment in which these abused children lived did not allow them to get a sense of security and a "sense of continuity".

During our third session, Anna tried to engage in a conversation and she posed questions about the tests for the first time.

The drawing of the human figure and of the House-Tree-Person Test indicates a reinforcement of the self-esteem. At the drawing of the human, she projected herself. Nothing was altered which indicates that the image of herself has changed. She will give a sexual identity to the person she drew. The feeling she expresses through the girl is happiness. Depressive aspects are not noted as well as at the drawing of the House-Tree-Person Test. The color and the light lines in the drawing reflect her self-esteem and emotional strengths. We no more observe a fragile and negative self-image. She identifies herself with the girl she drew. She presents now herself as a girl who feels happy and has beautiful eyes and hair revealing that her self-image is now a positive one. The size of the girl as well the size of the house and the tree can reflect strengths of the ego and a feeling of security. The inner strength of an individual might be suggested from the tree trunk drawn. Anna actually drew a big trunk. The house is also colored with bright colors and after our questions Anna reveals an attachment with the host family. Anna's answers to our questions indicate no more feelings of loneliness and weakness.

Like Anna, George gave a sexual identity to the human figure. It is a boy so we can think that he projected himself to his drawing. The fact that this time the figure is not very small and its facial characteristic are precise shows a change in how George presents himself. In addition, the House-Tree-Person Test indicates also that the image of himself has changed. He projects himself to the boy he drew and he presented him as a happy boy who loves playing with his friends. Depressive aspects are not noted. The size of the boy as well as the size of the house and the tree is normal. The dimensions of the drawing represent his level of self-esteem and 
confidence. Nothing is too small as in his previous drawings, during our first two sessions, leading us to think that his self-image was reinforced and became stronger. We can also observe this through his answers to our questions.

This change indicates a form of resilience on the part of Anna and George that would be related to changes in the family context. The elements that allow an injured child to become resilient are not extraordinary: to feel loved, to develop in a structuring framework, to discover that life makes sense. We can thus perceive the capacity of resilience not only as capacity that comes from the subject but also as the product of interaction with the environment. Resilience can be developed and variable according to circumstances of life and environmental contexts.

For children placed or adopted late research has shown that children who have suffered early deficiencies and who have delayed development have been able, as a result of their adoption, to recover from developmental delay. The work of Quinton and al. [19] in England on placements or adoptions of "big" children (adopted after the age of 12) demonstrated the adaptive capacities of social integration and good development (cognitive, psychoaffective and behavioral) in children who were adopted late, after experiencing early maternal deficiencies.

Furthermore, the research of Rushton and al. [20] mentions that when new parents were interviewed they reported that $73 \%$ of the children had formed an attached relationship with one or both parents by the end of their first year in placement. In addition, attachment classifications for children in foster care can be markedly different from those in institutional group or to foster care [21].

The results of our research are in line with the results of the researches mentioned above and show that even if the children had been subjected to abuse by their biological parents, the feeling of security and their attachment with the host family had changed the way they perceive themselves.

\section{CONCLUSIONS}

This research has shown that the violence and insecurity that characterize abusive relationships have altered the development of the child's self-image, which appears negative and insecure. It has been demonstrated that the early, violent relationships that the children of our research had experienced have weakened their ego and narcissism. However, the removal from an abusive family context, can help the children to reinforce their self-image.

These results show that the phenomenon of resilience is not rigid and can be developed through children's lives and in relation to the environmental context. The presence of a new identificatory model can be very beneficial for children. The presence of one or more "resilient tutors" help the children to reconstruct their identity. An important aspect for the children is to have someone who will combine affection with self-control, understanding, and the ability to enjoy their company and play with them [22]. Thus, abused children are still able to identify themselves with a new identificatory target and can therefore integrate the values or ways of being that the identificatory target manifests in his/her everyday life.

\section{References}

Holmes, M. R., Yoon, S., Voith, L. A., Kobulsky, J. M. and Steigerwald, S. (2015). Resilience in Physically Abused Children: Protective Factors for Aggression. Behav. Sci., 5(2), 176-189

Winnicott, D. W. (1965). Ego Distortion in Terms of True and False Self. The Maturational Process and the Facilitating Environment: Studies in the Theory of Emotional Development. New York: International Universities Press, 140-152 
Dolto, F. (1997). Le sentiment de soi : aux sources de l'image et du corps. Paris: Gallimard.

Freud, S. (1914b). On narcissism: An introduction. Standard Edition, 14, 67-102

Winnicott, D. W. (1967). Mirror-Role of Mother and Family in Child Development. In Playing and Reality. London: Tavistock, 1971, pp. 111-118.

Cyrulnik B. and al., (1998). Ces enfants qui tiennent le coup. Revigny-sur-Ornain : Hommes et Perspectives.

Gilligan R. (1997). Beyond permanence? Resilience in child placement practice and planning. Adoption and Fostering, 2 (1) p.12-20

Rutter, M. (1993). Resilience: Some Conceptual Considerations. Journal of Adolescent Health, 14, (8), 626-631

André C., Lelord F. (1999). L'éstime de soi. Paris : Odile Jacob

Waiswol, N. (1995). Projective techniques as psychotherapy. American journal of psychotherapy.

Machover, K. (1949). Personality Projection in the Drawing of the Human Figure: A Method of Personality Investigation. Springfield, IL: Thomas.

Corman, L. (1972). Le Test de Patte-Noire. 1er tome, PUF, Paris, 257 p.

Schröfl, S. (1977). The use of the "Patte Noire" test with children. Praxis der Kinderpsychologie und Kinderpsychiatrie, 26(5), 184-193.

Cohen, O., \& Ronen, T. (1999). Young children's adjustment to their divorce as reflected in their drawings. Journal of Divorce and Remarriage, 30, 47-70.

Bellak, L., \& Bellak, S. (1949). Children's Apperception Test. New York: C.P.S. Co.

Buck, J. N. and Warren, W. L. (1992). The House-Tree-Person projective drawing technique: Manual and interpretive guide. Revised edition. Los Angeles, CA: Western Psychological Services.

Freud, A. (1936, 1966). The Ego and Mechanisms of Defense. New York: International Universities Press, Inc.

Anzieu, D. (1989). The skin ego (C. Turner, Trans.). New Haven, CT, US: Yale University Press.

Quinton, D., Rushton, A., Dance, C. and Mayes, D. (1998). Joining New Families: A study of adoption and fostering in middle childhood. Chichester: Wiley.

Rushton, A., Deborah Mayes, Cherilyn Dance, David Quinton. (2003). Parenting Late-Placed Children: The Development of New Relationships and the Challenge of Behavioural Problems. Clinical Child Psychology and Psychiatry, 8(3), 389-400

Smyke, A. T., Zeanah, C. H., Fox, N., A., Charles A. Nelson, C., A. and Guthrie, D. (2010). Placement in Foster Care Enhances Quality of Attachment Among Young Institutionalized Children Child Dev., 81(1), 212-223.

De Tychey, C., Lighezzolo-Alnot, J., Claudon, P., Garnier, S., \& Demogeot, N. (2012). Resilience, mentalization, and the development tutor: A psychoanalytic and projective approach. Rorschachiana, 33(1), 49-77. 
APPENDIX

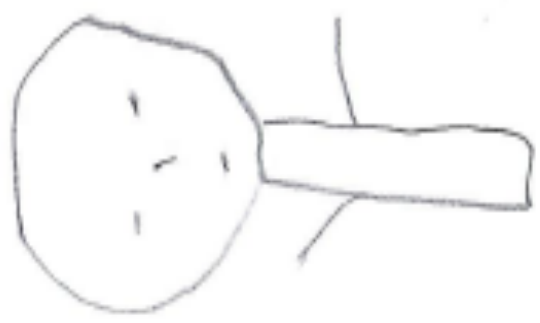

Appendix 1: Anna's Human Figure Drawing 


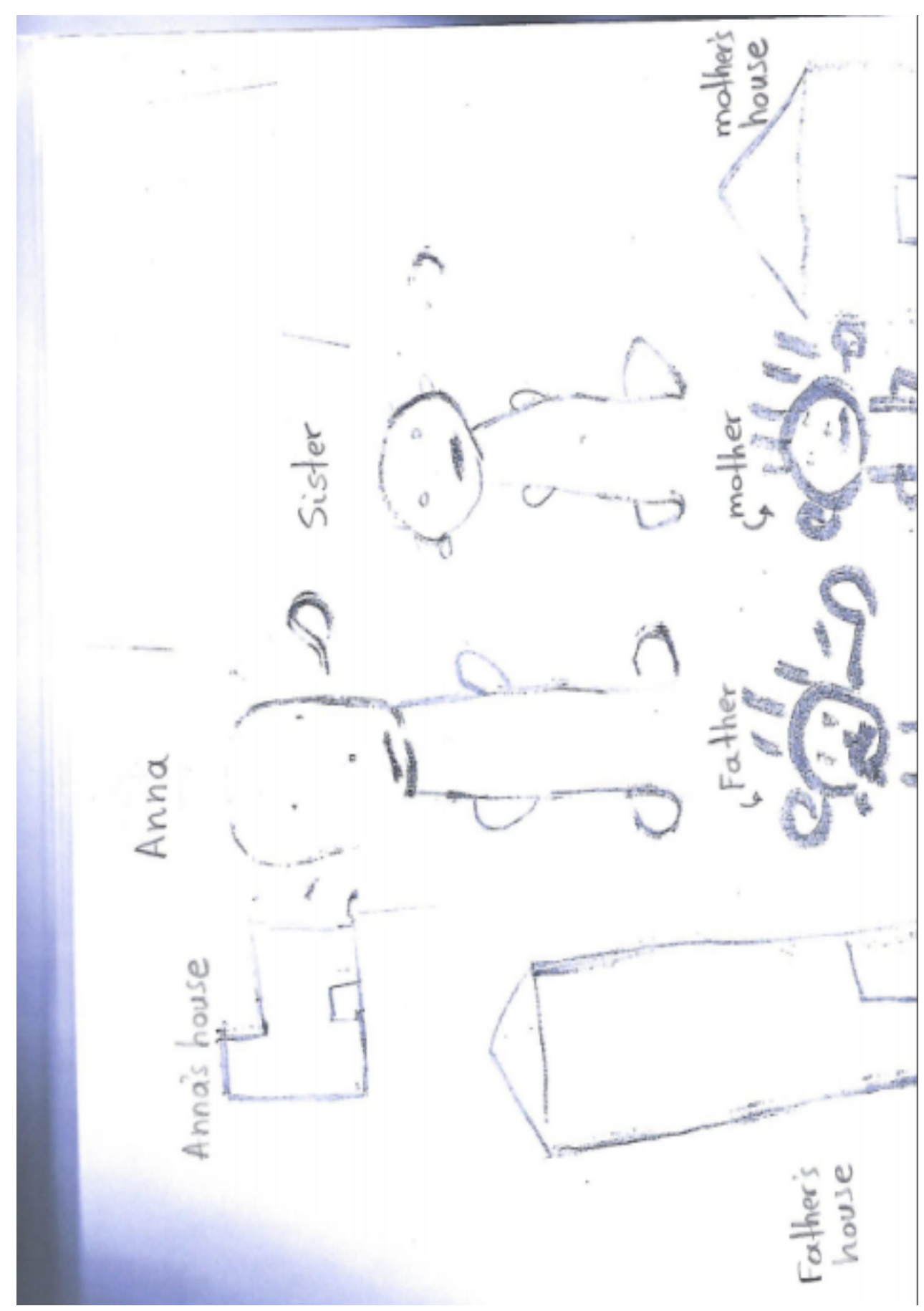

Appendix 2: Anna's drawing of her family 


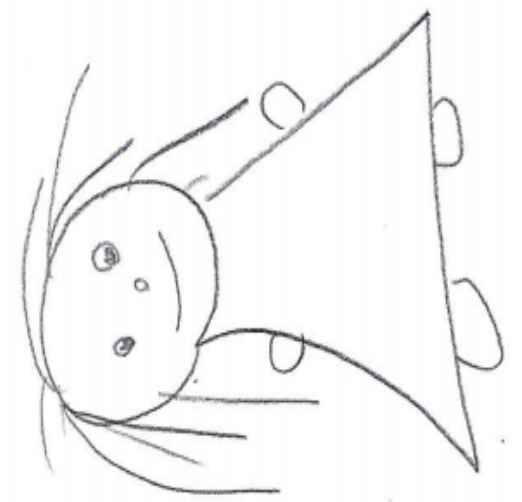

Appendix 3: Anna's second Human Figure Drawing 


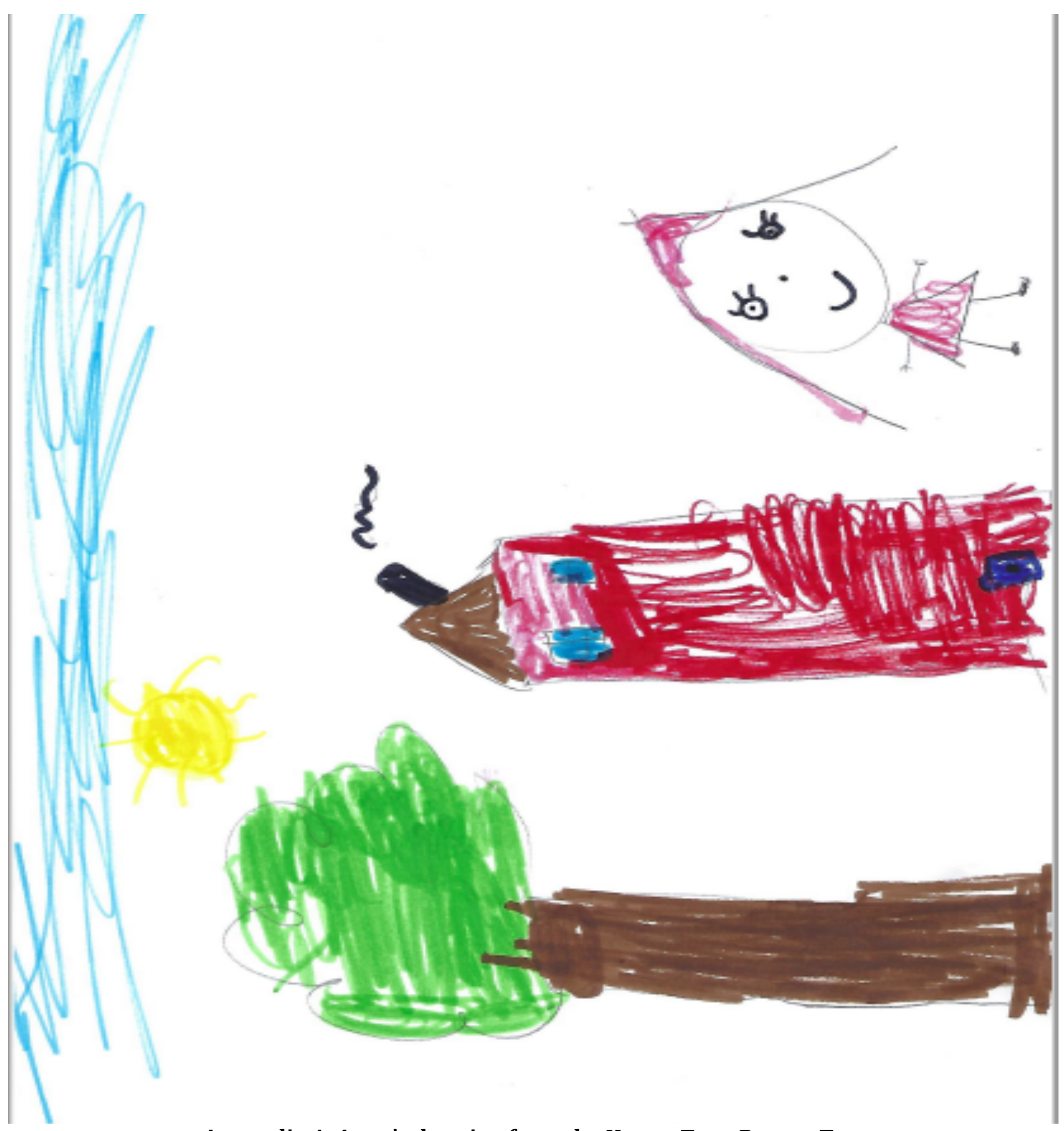

Appendix 4: Anna's drawing from the House-Tree-Person Test 
Appendix 5: George's Human Figure Drawing 

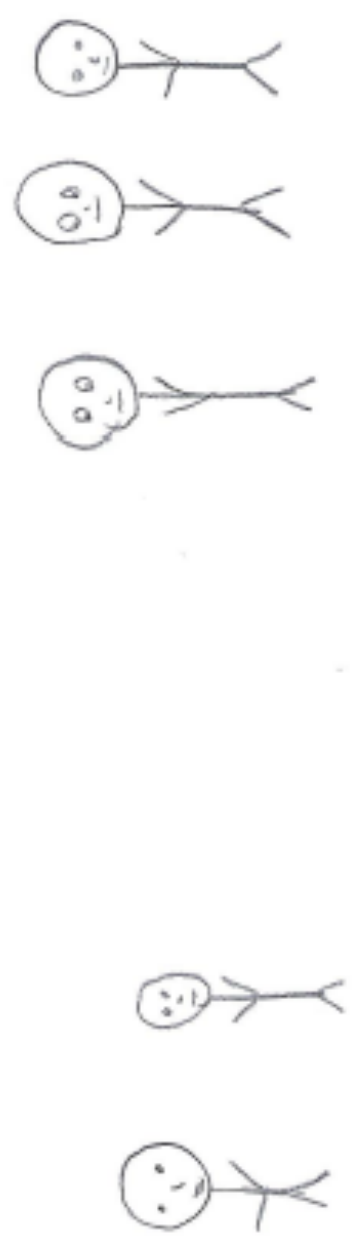

Appendix 6: George's drawing of his family 


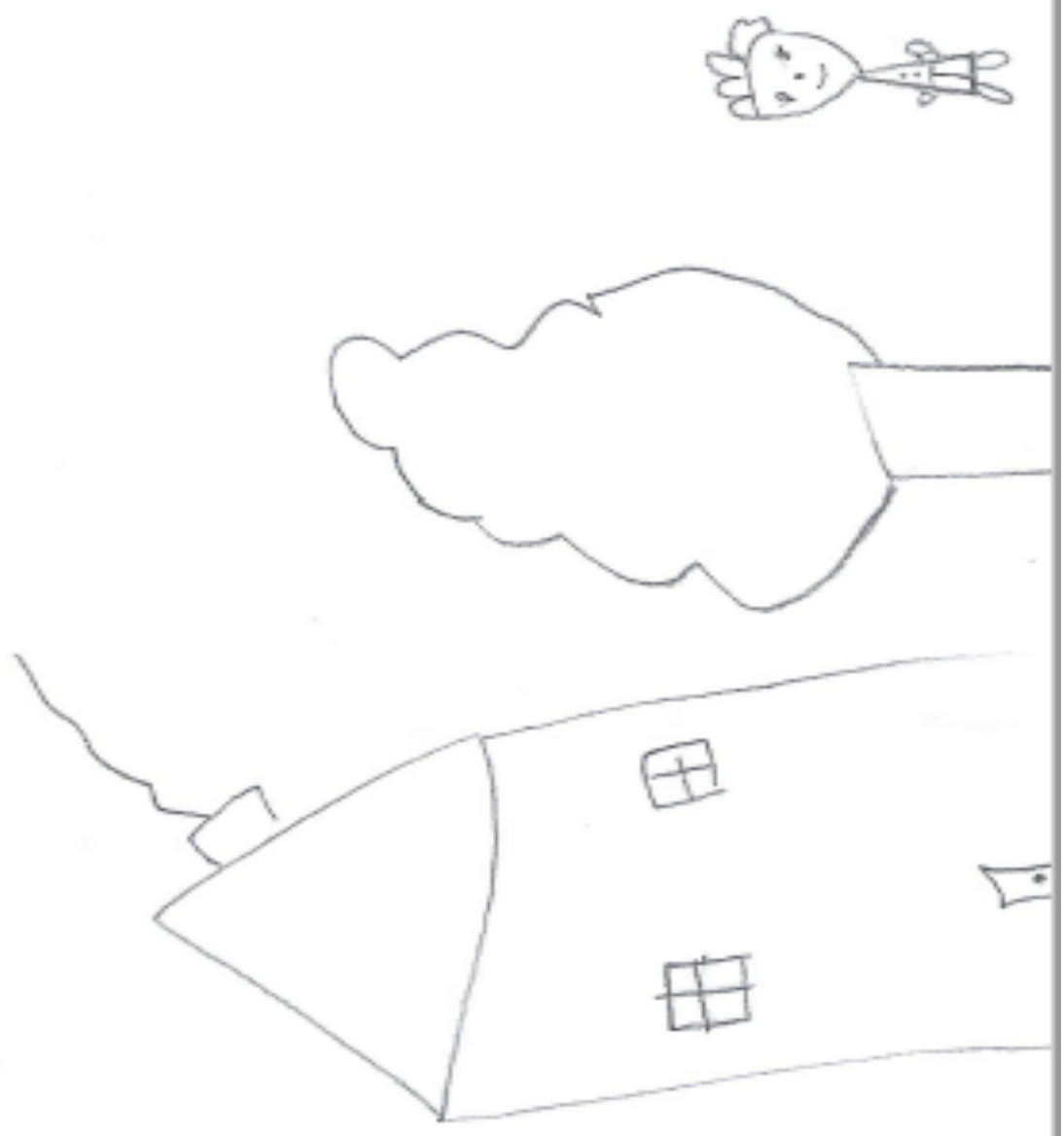

Appendix 6: George's drawing from the House-Tree-Person Test 